\title{
Dobre praktyki edukacji pozaformalnej
}

DOI: 10.47050/65591760.220-233

Renata Rettinger

Edukacja pozaformalna to uznany i coraz bardziej rozpowszechniony sposób zdobywania i rozwijania kompetencji, uczenia się o świecie, o innych, a także o sobie samym. Nowa ekonomia bazująca na wiedzy, informacji, innowacjach, postępie technologicznym tworzy nowe wyzwania edukacyjne, społeczne, gospodarcze i polityczne. Powyższe cele można realizować przez edukację pozaformalną. Współcześnie obserwuje się przesunięcie akcentu z edukacji formalnej, w której wiedza ma charakter obiektywny, na rzecz edukacji pozaformalnej. Głównym celem artykułu jest analiza inicjatyw edukacyjnych z zakresu kształtowania postaw przedsiębiorczych realizowanych w różnych formach i przez różne organizacje.

\section{Słowa kluczowe:}

\section{edukacja}

edukacja pozaformalna

postawy przedsiębiorcze

przedsiębiorczość 


\section{Good practices \\ in non-formal education}

DOI: 10.47050/65591760.220-233

Renata Rettinger

Non-formal education is a recognized and increasingly widespread way of acquiring and developing competence, also learning about the world, others, and yourself. New economy is based on knowledge, information, innovation, technological progress. It creates new educational, societal, economic, and political challenges. Above goals can be realized through non-formal education. Nowadays the emphasis on formal education, were the knowledge has an objective character, is shifting towards non-formal education. The main goal of this paper is the analysis of the educational initiatives from the scope of basic entrepreneurship realised through different forms and by different organizations.

\section{Keywords:}

\section{education}

non-formal education

entrepreneurial attitudes

entrepreneurship 


\section{Wstęp}

Współczesne tendencje rozwoju cywilizacyjnego na świecie, a w szczególności rozwój gospodarki opartej na wiedzy i kształtowanie społeczeństwa informacyjnego, powodują powstanie nowych wyzwań przed procesem edukacji na wszystkich jej poziomach (Dorocki, Kilar, Rachwał 2011; Piróg 2005; Stalończyk 2014; Wach 2013). Ta zmiana powinna polegać na dostosowaniu celów, treści, metod i zakładanych efektów kształcenia szkolnego do wyzwań czekających młode pokolenie w szybko zmieniających się realiach społeczno-gospodarczych. Należy sobie postawić pytanie: Czy system edukacji w Polsce jest w stanie sprostać wymaganiom współczesnego świata, przed którymi staje polski obywatel, gdzie nieustanny postęp technologiczny, innowacje, globalizacja wywierają tak ogromny wpływ na życie każdego z nas (Stalończyk 2014)? Bezsprzecznie kształcenie jest podstawą do budowania kapitału intelektualnego społeczeństwa (Rachwał, Wach 2016; Borowiec-Gabryś, Kilar, Rachwał 2018). Nauka szkolna stanowi tylko jedną część składową edukacji globalnej, jest ona uzupełniana o kształcenie i wychowanie pozaformalne, które odbywa się w szkole i poza nią, wybiega poza program szkolny i staje się bardziej czułe na zmiany dokonujące się w świecie. Należy pamiętać - aby jednostka potrafiła wykorzystać wszelkie możliwości uczenia się i doskonalenia, musi zdobyć dobre wykształcenie formalne (szkolne) i w efektywny sposób korzystać z innych form edukacji, a w szczególności z pozaformalnych (Trempała 2011).

W polskim szkolnictwie nadal dominuje klasyczny model nauczania. Natomiast współczesny model kształcenia przedsiębiorczego wymaga natychmiastowej implementacji, i to na szeroką skalę, co z kolei wymaga odpowiedniego przeszkolenia nauczycieli, ale przede wszystkim sporych nakładów finansowych na wyposażenie szkół i uczelni publicznych (Wach 2013). Niemniej istnieje pilna potrzeba zapewnienia wsparcia metodycznego dla nauczycieli przedsiębiorczości w zakresie wykorzystania aktywnych metod nauczania (m.in. takich jak moderacja wizualna, blended e-learning, edutainment). Aktywizujące metody nauczania powinny być szeroko stosowane w edukacji ekonomicznej na wszystkich poziomach edukacji szkolnej. Kształcenie takie wymaga zatem stosowania szerokiego wachlarza metod aktywizujących, szczególnie aktywizujących metod problemowych wyzwalających w uczących się własną inicjatywność (tamże). Jednym ze sposobów wdrożenia 
tych zmian w sposób kształcenia kompetencji przedsiębiorczych jest udział uczniów w inicjatywach edukacyjnych proponowanych w ramach edukacji pozaformalnej.

\section{Edukacja pozaformalna}

Edukacja formalna obejmuje naukę w systemie szkolnym. Kształcenie odbywa się w instytucjach szkolnych i edukacyjnych - zarówno państwowych, jak i prywatnych - zgodnie z odgórnie zatwierdzonymi programami i planami nauczania. Edukacja ta prowadzi w kierunku uzyskania kwalifikacji potwierdzonych świadectwem, zaświadczeniem o skończeniu szkoły, certyfikatem, dyplomem (Stalończyk 2014). W. Okoń (1998) definiuje kształcenie nieformalne/pozaformalne jako świadomą i zorganizowaną działalność o charakterze kształcenia i wychowywania, prowadzoną poza ustawowym formalnym systemem szkolnym, umożliwiającą określonej grupie uczestników osiągnięcie założonych celów kształcenia.

Edukacja pozaformalna w Polsce jest w początkowej fazie rozwoju, natomiast na arenie międzynarodowej stała się częścią polemiki nad polityką edukacyjną w latach 60. i 70. XX w. M. Fordham (1993) wyodrębnił cztery kluczowe elementy związane z kształceniem pozaformalnym:

$\rightarrow$ miejsce realizacji zajęć wyznaczone jest zarówno w obrębie instytucji edukacyjnych, jak i poza nimi,

$\rightarrow$ uczestnicy to osoby w różnym przedziale wiekowym, lecz o ściśle określonych potrzebach,

$\rightarrow$ program kształcenia pozaformalnego skoncentrowany jest na osiągnięciu określonych celów,

$\rightarrow$ elastyczność w organizacji i metodach nauczania, przekazywania wiedzy.

Edukacja pozaformalna obejmuje wszelkie zorganizowane, systematyczne działania edukacyjne, prowadzone poza ramami formalnego systemu, tak aby zapewnić poszczególne formy uczenia się różnym grupom wiekowym. Kształcenie pozaformalne jest elementem łączącym kształcenie ustawiczne z kształceniem przez całe życie. Uczenie się jest nieodzownym elementem naszej egzystencji, umożliwiającym adaptację do niestabilnych warunków życia. Jest to powód, dla którego nowa rzeczywistość edukacyjna przesycona jest ideą całożyciowego uczenia się (Marcinkiewicz 2013). Inwestycje związane z kształceniem 
podnoszą w sposób bezpośredni jakość kapitału ludzkiego. A on budowany jest przez rodzinę, środowisko, wzbogacany przez szkołę oraz system norm i dopiero w dojrzałej formie dostępny jest gospodarce. Tam może być rozwinięty i wykorzystany bądź stłamszony i zamordowany (Galar 2009).

\section{Formy oraz efektywność edukacji pozaformalnej}

Z każdym rokiem rośnie znaczenie edukacji pozaformalnej jako wyniku procesów dostosowawczych, zwiększających elastyczność rynku pracy w warunkach dynamicznie zmieniających się potrzeb społeczeństwa. Edukacja pozaformalna staje się coraz częściej ważnym źródłem wiedzy, umiejętności i kompetencji (Dziechciarz 2015). Zwiększone zapotrzebowanie ze strony osób podnoszących swoje kwalifikacje lub rozszerzających swoje kompetencje wymusza zmiany w ofercie kształcenia pozaformalnego. Popularność tego typu kształcenia skutkuje tworzeniem bogatej oferty form organizacyjnych. Edukacja pozaformalna to programy szkoleniowe świadczone przez instytucje społeczne, takie jak: biblioteki, muzea, szkoły muzyczne, szkoły językowe, domy kultury, teatry $\mathrm{i}$ inne organizujące aktywne formy spędzania wolnego czasu. Edukacja pozaformalna (non-formal education) odnosi się do aktywności edukacyjnych, sytuujących się poza formalnym systemem oświaty, takich jak: kursy, seminaria, odczyty koła miłośników, różne formy dokształcania, studia podyplomowe (Marcinkiewicz 2013).

Edukacja pozaformalna jest skierowana do różnych grup wiekowych. Decyzja o udziale w tego typu kształceniu może być podejmowana dobrowolnie w przypadku młodzieży uniwersyteckiej czy osób starszych lub inspirowana przez nauczyciela na niższych poziomach edukacyjnych. W przypadku dzieci i młodzieży edukacja pozaformalna powinna być atrakcyjna i interesująca, tak aby zaszczepić chęć do ciągłego uczenia się, rozwijania talentów i umiejętności. Współcześnie obserwuje się przesunięcie akcentu z edukacji formalnej, w której wiedza ma charakter obiektywny, a jej celem jest wyposażenie jednostki w kompetencje "twarde", na rzecz edukacji pozaformalnej, gdzie wiedza jest intersubiektywna i oferuje kompetencje "miękkie" (Marcinkiewicz 2013).

Kształcenie pozaformalne w połączeniu z formalnym charakteryzuje się bardzo dużą efektywnością. Można użyć sformułowania, że jest ono katalizatorem kształcenia formalnego. Aktywne uczestnictwo w projek- 
cie, realizacji zadania to aż 90 proc. zapamiętanej wiedzy. Pozaformalne uczenie się nie jest obowiązkiem, lecz przyjemnością lub bardzo często wyborem. Uczestnikom proponuje się wspólną realizację projektów oraz aktywne uczestnictwo w różnego rodzaju warsztatach i pracach zespołowych. Uczenie się poza szkołą jest efektywne, ponieważ zaangażowanie uczestnika aktywuje jego proces poznawczy. W ten sposób uczestnicy odkrywają swoje talenty, są zadowoleni z osiągniętych celów, budują więzi społeczne, kształtują poglądy i aktywnie spędzają czas. Kształtowane są pożądane postawy obywatelskie, takie jak odpowiedzialność społeczna, umiejętność porozumiewania się w grupie, szacunek dla innych osób, umiejętność szybkiego podejmowania decyzji, odwaga i upór w dążeniu do realizacji swoich celów oraz najważniejsze: potrzeba wzbogacania wiedzy. Uczestnictwo dobrowolne, oparte na pluralizmie działań, pozwala na indywidualność i samodzielność wyboru pomiędzy ofertami składanymi przez różnorodne pozaszkolne ośrodki edukacji a proponowanymi formami pracy i treściami charakteryzującym nowość (aktualność), innowacyjność, siła przyciągania, różnorodność i adekwatność wobec potrzeb i oczekiwań (Trempała 2011). Najważniejszym problemem jest powiązanie edukacji formalnej z pozaformalną, czyli w planowanej pracy nauczycieli szkolnych powinny znaleźć odbicie wielorakie nieszkolne wpływy edukacyjne, oddziałujące na uczniów, czyli cały proces kształcenia i wychowania szkolnego należy włączyć w nurt dopełniających go oddziaływań nieszkolnych.

Stroną organizacyjną edukacji pozaformalnej zajmują się liczne instytucje i organizacje publiczne, prywatne oraz podmioty organizacyjne wchodzące w skład sektora non profit. W Polsce po 1989 r. organizacje pozarządowe zaczęły pojawiać się masowo, wynikało to w dużej mierze z procesów demokratyzacji kraju i tworzenia się społeczeństwa obywatelskiego (Rudnicki 2015). Charakter polskiego systemu edukacyjnego (edukacja formalna) stworzył miejsce dla działań quasi-instytucji zajmujących się edukacją pozaformalną, które w ciekawy i nowatorski sposób mają przedstawić oraz przekazać wiedzę bardzo często pomijaną przez placówki oświatowe. Tak właśnie było z edukacją "o" przedsiębiorczości, „dla” przedsiębiorczości i „przez” przedsiębiorczość. Uczelnie wyższe jako instytucje edukacji trwającej przez całe życie nie są jedynie placówkami kształcenia formalnego, lecz także instytucjami, w których odbywa się kształcenie pozaformalne i nieformalne. Ten typ działalności zapewnia dostęp do edukacji na najwyższym poziomie oraz 
kontakt z wykładowcami akademickimi (Marcinkiewicz 2013). Edukacja nieszkolna to wielki i bardzo różnorodny obszar, w ramach którego niektóre instytucje swoją atrakcyjnością zajęć oraz aktualnością wiedzy i informacji prowokują ich uczestników do wyboru różnorodnych form pracy oraz treści kształcących (Trempała 2011).

Problemem, który trzeba będzie w najbliższych latach rozwiązać, jest kwestia uznawalności kształcenia pozaformalnego. Certyfikaty uzyskane w ramach kształcenia pozaformalnego poświadczają jedynie zdobycie pewnego rodzaju wiedzy, umiejętności i kompetencji. Jedną z najpopularniejszych form są studia podyplomowe, które umożliwiają zdobycie w relatywnie krótkim czasie (dwa-cztery semestry) określonych kwalifikacji i kompetencji często o charakterze specjalistycznym (Marcinkiewicz 2012).

\section{Dobre praktyki edukacji pozaformalnej w zakresie przedsiębiorczości}

Mnogość działań edukacyjnych na współczesnym rynku edukacji pozaformalnej wymusza krytyczne podejście do angażowania się szkół w projekty edukacyjne z zakresu szeroko rozumianej przedsiębiorczości. W dalszym ciągu istnieje bardzo duże zapotrzebowanie na prowadzenie dodatkowych zajęć z zakresu kształtowania i rozwijania u uczniów kluczowych kompetencji (społecznych, inicjatywności, przedsiębiorczości) oraz kształtowania właściwych postaw (kreatywności, innowacyjności, pracy zespołowej) niezbędnych na rynku pracy. Dobre przykłady edukacji pozaformalnej to: pikniki naukowe, Centrum Nauki Kopernik, program "Młodzież w działaniu", uniwersytet trzeciego wieku, wycieczki i obozy przyrodnicze, Noc Muzeów, obozy językowe, festyny naukowe. Proces przeorientowania systemu edukacji jest trudny i długofalowy. Działania nie mogą być tylko odgórne, ponieważ nie będą przynosiły efektów. Współpraca na poziomie lokalnym pomiędzy szkołami a lokalnymi organizacjami, takimi jak domy kultury, teatry, biblioteki, fundacje czy stowarzyszenia, powinna zostać wpisana w ramy polityki edukacyjnej na poziomie wszystkich jednostek samorządu terytorialnego.

Poniżej zostały przedstawione wybrane inicjatywy edukacyjne z zakresu przedsiębiorczości, prowadzone przez różnego rodzaju organizatorów oraz o różnym zakresie wiedzy i stosowanych metodach edukacyjnych. 
Jedną z instytucji państwowych prowadzących również działalność edukacyjną jest Narodowy Bank Polski, który w dokumencie „Priorytetowe obszary edukacji ekonomicznej NBP w 2018 r." za czwarty obszar priorytetowy uznał "Rozbudzanie postaw i zachowań przedsiębiorczych, zarządzanie przedsiębiorstwem". NBP w ramach swojej działalności edukacyjnej wspiera finansowo inicjatywy i projekty z zakresu edukacji ekonomicznej. Dofinansowywane są m.in.: konkursy, olimpiady przedmiotowe, warsztaty, szkolenia, wykłady, konferencje, a publikacje naukowe dystrybuowane są bezpłatnie. Innym przykładem dobrych praktyk są działania NBP w ramach portalu edukacyjnego (www.nbportal.pl/edukacja-w-nbp). Znajduje się tam wiele zasobów, które można wykorzystać w szeroko rozumianej edukacji o przedsiębiorczości. Są to: artykuły, prezentacje, Klub Nauczycieli „Impuls”, i-przedsiębiorczość, scenariusze lekcji, gry, komiksy, krzyżówki, filmy, quizy. NBP oferuje również możliwość dofinansowania projektów edukacyjnych w wysokości do 30 tys. zł (Bieńkowska 2017).

Inicjatywy edukacyjne podejmowane są także przez organy samorządu terytorialnego. Do ciekawych należy inicjatywa władz Wrocławia, która nie tylko wpływa na postawy przedsiębiorcze mieszkańców, lecz także przede wszystkim ma pomóc kształtować społeczeństwo obywatelskie (Oficjalny portal internetowy Wrocławia 2018). Według autorów tego projektu jest to nauka przez zabawę, w trakcie której kształtowane są postawy przedsiębiorcze beneficjentów programu, a w szczególności cechy: aktywność i ekspansywność, umiejętność oceny ryzyka i gotowość do jego podjęcia, akomodacja w zmieniających się warunkach, praca w zespole, dostrzeganie szans i ich wykorzystanie, innowacyjność. Długofalowymi celami Programu Edukacja Przedsiębiorczości są: popularyzacja przedsiębiorczości jako kompetencji pożądanej na rynku pracy oraz - nie mniej ważne - powstawanie w przyszłości we Wrocławiu większej liczby firm, konkurencyjnych w warunkach gospodarki rynkowej (www.wroclaw.pl). W ciągu 10 lat funkcjonowania programu zrealizowano 19 przedsięwzięć. Wszystkie materiały szkoleniowe są upublicznione na stronie programu i mogą z nich korzystać inne samorządy, organizacje pozarządowe, instytucje oświatowe i osoby prywatne. We Wrocławiu w ramach programu uruchomiono innowacyjny dwuletni projekt "Słowa mają moc". W trakcie jego trwania 26 nauczycieli zostanie przeszkolonych z innowacyjnych technik prowadzenia zajęć, 390 uczniów będzie się szkoliło z efektyw- 
nej komunikacji, a 1170 uczniów dowie się więcej o biznesie dzięki kontaktom z innowatorami zaproszonymi na cykliczne spotkania do szkół.

W Lublinie rusza pilotażowy projekt "Przedsiębiorcze dzieciaki". Zostanie nim objętych 200 dzieci z Lublina w wieku 6-10 lat. Celem przedsięwzięcia jest nauka postaw przedsiębiorczych, które w przyszłości będą przydatne na rynku pracy i pomogą w rozwijaniu kariery zawodowej. Projekt "Przedsiębiorcze dzieciaki” powstał z inicjatywy Wydziału Strategii i Obsługi Inwestorów Urzędu Miasta Lublina i Wydziału Pedagogiki i Psychologii UMCS (Lublin Miasto Inspiracji 2018). Pierwsza, pilotażowa edycja trwała od marca do czerwca 2018 r. Wzięło w niej udział dziewięć placówek oświatowych z Lublina i okolic. O przedsiębiorczości uczyło się ponad 350 dzieci pod kierunkiem 23 nauczycieli i 11 studentów z Koła Naukowego Pedagogów i Animatorów Zabawy. Tematyka projektu koncentrowała się na przedsiębiorczości rozumianej jako twórcza i kreatywna postawa oraz umiejętność prezentowania pasji, radzenia sobie ze stresem i pozyskiwania środków finansowych na spełnianie marzeń. Partnerami akcji był Bank Millennium oraz Narodowy Bank Polski. Częścią projektu była również wizyta w lubelskich firmach, które z powodzeniem zaprezentowały się przedszkolakom i uczniom.

Ciekawy projekt edukacyjny został zorganizowany z kolei przez Gdański Inkubator Przedsiębiorczości Starter i miasto Gdańsk (Portal Miasta Gdańska 2018). Od 2014 r. w Lekcjach Przedsiębiorczości łącznie wzięło udział ponad 2,5 tys. uczniów. Program oferuje zgamifkowane zajęcia z przedsiębiorczości, podczas których młodzież zdobywa biznesową wiedzę na specjalnej platformie działającej podobnie do znanych gier. Celem programu jest zmiana sposobu uczenia przedsiębiorczości w gimnazjach i liceach, rozwijanie ich kompetencji oraz postaw przedsiębiorczych.

Bardzo często inicjatywy w obszarze edukacji przedsiębiorczości podejmowane są przez organizacje pozarządowe. Jedną z ważniejszych organizacji jest Fundacja Młodzieżowej Przedsiębiorczości (www.junior.org.pl). Jest to pozarządowa organizacja pożytku publicznego, której celem jest przygotowanie dzieci i młodzieży do życia w warunkach gospodarki rynkowej oraz umożliwienie młodym ludziom zdobycia wiedzy i praktycznych umiejętności ułatwiających realizację planów zawodowych. Fundacja Młodzieżowej Przedsiębiorczości jest trzecią co do wielkości organizacją Junior Achievement na świecie pod względem liczby uczniów - w programach wzięło już udział ponad $7 \mathrm{mln}$ 
młodych ludzi. W ofercie fundacji znajdują się następujące programy: "Od grosika do złotówki”, „Ekonomia na co dzień" , „Dzień Przedsiębiorczości”, "Młodzieżowe miniprzedsiębiorstwo”, „Moje finanse”, „Podstawy przedsiębiorczości”, „Zarządzanie firmą".

Kolejne dobre praktyki to inicjatywy Fundacji Obywatelskiego Rozwoju (FOR) realizowane we współpracy m.in. z MEN i Ośrodkiem Rozwoju Edukacji. Każda edycja programu to konkurs na komiksy o tematyce ekonomicznej, scenariusze lekcji, animacje czy możliwość zaproszenia przedstawicieli projektu do poprowadzenia wybranych lekcji w szkole (Bieńkowska 2017).

W edukację pozaformalną wpisują się działania w zakresie rywalizacji uczniowskiej i studenckiej w ramach olimpiad przedmiotowych. Do takich inicjatyw należy m.in. Szkolna Olimpiada Przedsiębiorczości (od 2005 r.), której organizatorem jest Fundacja Promocji i Akredytacji Kierunków Ekonomicznych (od 2008 r. prowadzi też dwa ogólnopolskie projekty edukacyjne - Akademię Młodego Ekonomisty oraz Ekonomiczny Uniwersytet Dziecięcy). Celem tych projektów jest popularyzacja wiedzy i budowanie świadomości ekonomicznej dzieci i młodzieży (Fundacja Promocji i Akredytacji 2018). Organizacja podejmuje także wiele działań służących doskonaleniu jakości kształcenia w polskich szkołach wyższych oraz propagowaniu i wspieraniu jego najlepszych wzorców. Olimpiada Przedsiębiorczości jest formą współzawodnictwa edukacyjnego, podczas którego oceniane są wiedza, umiejętności oraz postawy ( $w$ tym przede wszystkim szeroko rozumiane postawy przedsiębiorcze), a także wyrażające je zachowania przedsiębiorcze.

Kolejną inicjatywą skierowaną do studentów kierunków ekonomicznych jest konkurs "Przedsiębiorczość, finanse i zarządzanie” (Fundacja Edukacyjna Przedsiębiorczości 2018). Zespoły studentów sprawdzają w nim swoją wiedzę i umiejętności, mierząc się z praktycznymi problemami występującymi w przedsiębiorstwach, oraz próbują swoich sił w negocjacjach. Misją konkursu jest promowanie integracji wiedzy z zarządzania i finansów, podstawowym zaś celem weryfikacja wiedzy i umiejętności nabytych na studiach oraz sprawdzenie zastosowania ich w praktyce. W 22 edycjach konkursu wzięło udział ponad 1,7 tys. studentów reprezentujących uczelnie wyższe z całej Polski.

Wiele instytucji i organizacji podejmuje działania zmierzające do kooperacji i wspierania metodycznego oraz szkoleniowego nauczycieli z zakresu przedsiębiorczości. W takie działania wpisują się oferty 
uniwersytetów proponujące studia podyplomowe, które są odpowiedzią na stale rosnącą konieczność zdobywania lub pogłębiania wiedzy teoretycznej z zakresu przedsiębiorczości oraz potrzebę doskonalenia umiejętności praktycznych. Konieczne są dalsze działania mające na celu organizacyjne, merytoryczne i metodologiczne wsparcie nauczycieli uczących na różnych poziomach edukacyjnych w zakresie przedsiębiorczości (Tracz, Rachwał 2007, Dorocki, Kilar, Rachwał 2011).

\section{Podsumowanie}

W dziedzinie wychowania i kształcenia współczesne społeczeństwo faktycznie nie zaspokoi swoich potrzeb za pośrednictwem jednej instytucji szkolnej, nawet najbardziej rozbudowanej. Koniecznością stało się wejście na rynek usług edukacyjnych organizacji i instytucji działających w edukacji pozaformalnej. Podmioty działające w obrębie edukacji pozaformalnej przejęły funkcję edukacji szkolnej w zakresie tematyki i metod upowszechniania wiedzy, marginalizowanej lub nieobecnej. Taka sytuacja istnieje w zakresie edukacji „o" przedsiębiorczości i „dla” przedsiębiorczości, szczególnie na niższych poziomach edukacyjnych. Edukacja pozaformalna przejęła inicjatywę tworzenia aktywnych, innowacyjnych form edukacji na różnych poziomach edukacyjnych. 


\section{Bibliografia}

$\rightarrow$ Bieńkowska, B. (2017), Przedsiębiorczość i innowacyjność - próba refleksji nad ich miejscem w systemie oświaty [w:] „Research Papers of the Wroclaw University of Economics/Prace Naukowe Uniwersytetu Ekonomicznego we Wrocławiu", (489), s. 44-56.

$\rightarrow$ Borowiec-Gabryś, M., Kilar, W., Rachwał, T. (2018), Przedsiębiorczość jako kompetencja przyszłości [w:] S.M. Kwiatkowski (red.), Kompetencje przyszłości, Seria Naukowa, t. 3, Warszawa: Fundacja Rozwoju Systemu Edukacji, s. 68-89.

$\rightarrow$ Dorocki, S., Kilar, W., Rachwał, T. (2011), Założenia i cele projektu „Krok w przedsiębiorczość" dla nauczycieli szkół ponadgimnazjalnych [W:] „Przedsiębiorczość - Edukacja", nr 7, s. 308-320.

$\rightarrow$ Dziechciarz, J. (2015), Pomiar i wycena wiedzy, umiejętności i kompetencji nabytych $w$ formalnych i nieformalnych formach kształcenia/Measurement and Valuation of Knowledge, Skills and Competence Acquired in the Formal and Informal Education Forms, s. 25-42.

$\rightarrow$ Galar, R. (2003), Gospodarka oparta na wiedzy - sześć wątpliwości, [w:] A. Kukliński (red.), Gospodarka oparta na wiedzy. Perspektywy Banku Światowego w Polsce, Biuro Banku Światowego w Polsce, KBN, Warszawa.

$\rightarrow$ Marcinkiewicz, A. (2012), Kształcenie podyplomowe wobec rynku pracy, „E-mentor", nr 2, s. 54-60.

$\rightarrow$ Marcinkiewicz, A. (2013), Pozaformalne i nieformalne aspekty edukacji akademickiej, "Ogrody Nauk i Sztuk", nr 3, s. 46-53.

$\rightarrow$ Okoń, W. (1998), Wprowadzenie do dydaktyki ogólnej, Warszawa: Wydawnictwo Akademickie Żak.

$\rightarrow$ Piróg, D. (2005), Miejsce i rola edukacji europejskiej w nauczaniu podstaw przedsiębiorczości w kontekście współczesnych wyzwań cywilizacyjnych, „Przedsiębiorczość - Edukacja”, nr 1, s. 213-220.

$\rightarrow$ Fordham, P.E. (1993), Informal, non-formal and formal education programmes, YMCA George Williams College ICE301 lifelong learning unit, 2. 
$\rightarrow$ Rachwał, T., Wach, K. (2016), Badanie intencji przedsiębiorczych młodego pokolenia: wyniki ankietyzacji wśród studentów kierunków nieekonomicznych, "Przedsiębiorczość - Edukacja”, nr 12, s. 405-415.

$\rightarrow$ Rudnicki, P. (2015), Edukacja globalna w polskich szkołach, czyli refleksje nad pozaformalnq zmianq w oświacie w trzech ujęciach [w:] M. Kuleta-Hulboj, M. Gontarska (red.), Edukacja globalna: polskie konteksty i inspiracje, Wrocław: Wydawnictwo Naukowe Dolnośląskiej Szkoły Wyższej. s. 60-90.

$\rightarrow$ Stalończyk, I. (2014), Edukacja formalna i pozaformalna w procesie kształtowania społeczeństwa wiedzy , "Nierówności Społeczne a Wzrost Gospodarczy” nr 37, s. 320-332.

$\rightarrow$ Tracz, M., Rachwał, T. (2007), Przedmiot podstawy przedsiębiorczości-założenia realizacji a przygotowanie nauczycieli, „Przedsiębiorczość - Edukacja”, $\mathrm{nr}$ 3, s. 286-296.

$\rightarrow$ Trempała, E. (2011), Edukacja formalna (szkolna) i edukacja nieformalna (równoległa, nieszkolna, pozaszkolna), [w:] „Przegląd Pedagogiczny", nr 1, s. 95-104.

$\rightarrow$ Wach, K. (2013), Edukacja na rzecz przedsiębiorczości wobec współczesnych wyzwań cywilizacyjno-gospodarczych, „Przedsiębiorczość - Edukacja”, nr 9, s. 246-257. 


\section{Netografia}

$\rightarrow$ Oficjalny portal internetowy Wrocławia, www.wroclaw.pl/biznes/edukacja-przedsiebiorczosci (dostęp 8.12.2018).

$\rightarrow$ Lublin Miasto Inspiracji, przedsiebiorczedzieciaki.lublin.eu (dostęp 8.12.2018).

$\rightarrow$ Portal Miasta Gdańska, www.gdansk.pl/inwestycje-miejskie/gdanski-inkubator-przedsiebiorczosci,a,18121 (dostęp: 8.12.2018).

$\rightarrow$ 6. Fundacja Promocji i Akredytacji Kierunków Ekonomicznych, www.fundacja. edu.pl/modul/3/114/297/szkolna_olimpiada_przedsiebiorczosci.html (dostęp: 8.12.2018).

$\rightarrow$ Fundacja Edukacyjna Przedsiębiorczości, fep.lodz.pl/pl/programy/konkurs-przedsiebiorczosc-finanse-i-zarzadzanie (dostęp: 8.12.2018). 